\title{
Enthalpy and Gibbs energy of formation of cerium dicarbide
}

\author{
R. Vidhya ${ }^{\text {a }}$, M.P. Antony ${ }^{\text {a }, ~ P . R . ~ V a s u d e v a ~ R a o ~}{ }^{\text {a,* }}$, B. Viswanathan ${ }^{\text {b }}$ \\ ${ }^{a}$ Fuel Chemistry Division, Chemical Group, Indira Gandhi Centre for Atomic Research, Kalpakkam 603 102, Tamil Nadu, India \\ b Department of Chemistry, Indian Institute of Technology, Madras 600 036, India
}

Received 24 July 2002; accepted 2 January 2003

\begin{abstract}
The equilibrium $\mathrm{CO}$ pressure over the condensed phase region of $\mathrm{CeO}_{2}(\mathrm{~s})-\mathrm{CeC}_{2}(\mathrm{~s})-\mathrm{C}(\mathrm{s})$ was determined by adopting a method termed as the dynamic effusion MS method, which involves the measurement of the CO effusing out from the sample using a quadrupole mass spectrometer, even during carbothermic reduction of the oxide. The formation of oxicarbide has been ruled out. The Gibbs energies of the reaction, $\mathrm{CeO}_{2}(\mathrm{~s})+4 \mathrm{C}(\mathrm{s})=\mathrm{CeC}_{2}(\mathrm{~s})+2 \mathrm{CO}(\mathrm{g})$, at various temperatures in the range 1350-1550 $\mathrm{K}$ were then determined from the equilibrium $\mathrm{CO}$ pressures. From the Gibbs energies of the reaction, the Gibbs energy of formation of $\mathrm{CeC}_{2}(\mathrm{~s})$ at $298 \mathrm{~K}$ was derived. Similarly, from the data on the second and third-law enthalpies of the above reaction, the enthalpy of formation of $\mathrm{CeC}_{2}(\mathrm{~s})$ at $298 \mathrm{~K}$ was calculated. The recommended Gibbs energy and enthalpy of formation of $\mathrm{CeC}_{2}(\mathrm{~s})$ at $298 \mathrm{~K}$ are (103.0 \pm 6.0$)$ and $(120.1 \pm 11.0)$ $\mathrm{kJ} \mathrm{mol}^{-1}$, respectively.

(c) 2003 Elsevier Science B.V. All rights reserved.
\end{abstract}

\section{Introduction}

Rare earths are an important class of fission products with a total yield of $45 \%$. The yield of cerium is about $10-12 \%$ of the total yield [1]. Cerium mimics plutonium in various properties. Hence, cerium and its compounds can be used as a stand-in for the corresponding plutonium compounds. There is a significant amount of thermochemical data for cerium dicarbides, determined by diverse techniques. The reported enthalpies of formation range between -60 and $-190 \mathrm{~kJ} \mathrm{~mol}^{-1}$. There is also an ambiguity in the sign of the reported entropy of formation of $\mathrm{CeC}_{2}(\mathrm{~s})$. Owing to the discrepancy in the reported data and in continuation with our earlier program $[2,3]$ to determine the thermodynamic data of solid rare earth dicarbides, the thermodynamic data of cerium dicarbide were measured in the temperature range 1350 $1550 \mathrm{~K}$ employing a novel dynamic effusion technique developed in our laboratory [4], and the results are re-

\footnotetext{
${ }^{*}$ Corresponding author. Tel.: +91-4114 280229; fax: +914114280065.

E-mail address: vasu@igcar.ernet.in (P.R. Vasudeva Rao).
}

ported in this paper. This new method is referred to as the dynamic effusion MS method henceforth in the paper.

There is no established phase diagram for the $\mathrm{Ce}-\mathrm{C}$ system, though the structures of the carbides have been adequately studied. Two binary carbides, $\mathrm{CeC}_{2}$ and $\mathrm{CeC}_{1.5}$, have been reported. $\mathrm{CeC}_{2}$ has two phase modifications, a low-temperature $\alpha$-phase (tetragonal) and a high-temperature $\beta$-phase (cubic) [5].

A tentative ternary diagram for the $\mathrm{Ce}-\mathrm{O}-\mathrm{C}$ system at temperatures below $1873 \mathrm{~K}$ has been reported by Clark and McColm [6]. Anderson and Bagshaw [7], have tried to determine the oxygen contamination in the binary cerium/carbon system and to investigate the possibility of oxygen stabilizing a cerium monocarbide phase with a rock-salt type structure. An extensive survey of the possibility of various types of oxycarbides in the $\mathrm{Ce}-\mathrm{C}-\mathrm{O}$ system is available in this paper, but no systematic study on their vaporisation behaviour has been reported. Pialoux [8] has reported the phase diagram of $\mathrm{Ce}-\mathrm{C}-\mathrm{O}$ system, valid in the temperature range 1610-2043 K. The compositions of some of the regions have not been fully established even in this recent phase diagram. 
The thermodynamic properties of a number of cerium carbides have been determined by mass spectrometry by Kingcade et al. [9]. The sublimation of $\mathrm{CeC}_{2}$ was investigated over the temperature range 1908-2309 $\mathrm{K}$ using Knudsen cell-mass spectrometry by Winchell and Baldwin [10] and they have concluded that the major gas species in equilibrium with $\mathrm{CeC}_{2}$ (s) is only $\mathrm{CeC}_{2}$. Faircloth et al. [11] have also studied the vapourisation of $\mathrm{CeC}_{2}(\mathrm{~s})$ in equilibrium with graphite in the temperature range 1900-2230 K using a Knudsen effusion-target collection method. They have observed the presence of $\mathrm{Ce}$ vapours also along with that of $\mathrm{CeC}_{2}$ over $\mathrm{CeC}_{2}(\mathrm{~s})$ phase and also state that the $p_{\mathrm{CeC}_{2}} / p_{\mathrm{Ce}}$ ratio is about 0.77 at $2000 \mathrm{~K}$. A Knudsen cell-mass spectrometric investigation of the gaseous phase in thermodynamic equilibrium with the condensed phases of the cerium-carbon system has been reported by Balducci et al. [12] in the temperature range 1900-2300 K. The composition of the condensed phase was assumed to be close to that of dicarbide and the ratio of the vapour pressures $\left(p_{\mathrm{CeC}_{2}} / p_{\mathrm{Ce}}\right)$ above the condensed phase was observed to be four in the entire temperature range. The enthalpies of formation of cerium sesquicarbide and cerium dicarbide have been determined by oxygen-bomb calorimetry by Baker et al. [13]. Anderson and Bagshaw [14] have determined the thermodynamic data for the $\mathrm{CeC}_{2}$ (s) in the temperature range $900-1300 \mathrm{~K}$ using a $\mathrm{CaF}_{2}$ solid-electrolyte galvanic cell method. The second and third-law enthalpies of formation of $\mathrm{CeC}_{2}(\mathrm{~s})$ reported by Anderson and Bagshaw [14] differ significantly. The standard enthalpy of formation of $\mathrm{CeC}_{2}(\mathrm{~s})$ at $298 \mathrm{~K}$ has been determined by Meschel and Kleppa [15] by employing direct synthesis calorimetry. Pialoux [8] has studied the carbothermic reduction of $\mathrm{CeO}_{2}(\mathrm{~s})$ by maintaining a controlled $\mathrm{CO}$ pressure (between $10^{-6}$ and 1 bar) in the temperature range $1600-2000 \mathrm{~K}$ and has determined the standard Gibbs energies of formation of various compounds, which appear during the progress of the reaction. The phases were confirmed by means of a high-temperature X-ray diffraction study. There exists a compilation of the estimated Gibbs energy of formation of all the rare earth carbides in the report by Gschneidner and Kippenhan [16] and Gschneidner and Calderwood [17]. Niessen et al. [18] have estimated the enthalpy of formation of $\mathrm{CeC}_{2}(\mathrm{~s})$ using Miedema's semi-empirical method. The data on the enthalpy of formation of the dicarbide at $298 \mathrm{~K}$ reported based on various methods have been tabulated in this paper.

In the present study, a novel dynamic effusion method has been used to determine the equilibrium $\mathrm{CO}$ pressures over the condensed phases of carbide/oxide and graphite. Details of the method can be found in Ref. [4]. This method termed as the dynamic effusion MS method involves generating the carbide 'in situ' in a high vacuum chamber (ultimate pressure $10^{-9}$ bar) from a mixture of $\mathrm{CeO}_{2}$ (s) and graphite as per the following equation

$\mathrm{CeO}_{2}(\mathrm{~s})+4 \mathrm{C}(\mathrm{s})=\mathrm{CeC}_{2}(\mathrm{~s})+2 \mathrm{CO}$

The equilibrium $\mathrm{CO}$ pressure over the resulting phase field $\mathrm{CeO}_{2}(\mathrm{~s})-\mathrm{C}(\mathrm{s})-\mathrm{CeC}_{2}(\mathrm{~s})$ was derived from the effusion pressure of $\mathrm{CO}$ from the sintered pellet as determined by means of a quadrupole mass spectrometer (QMS) [4]. From the equilibrium carbon monoxide pressures, the Gibbs energy of formation and the enthalpy of formation (by second and third-law methods) of $\mathrm{CeC}_{2}(\mathrm{~s})$ at $298 \mathrm{~K}$ were derived using appropriate data for $\mathrm{CeO}_{2}(\mathrm{~s}), \mathrm{C}(\mathrm{s})$ and $\mathrm{CO}$ from the literature [19]. An independent high-temperature XRD study, to observe the formation of phases during the progress of the reaction, was also undertaken.

\section{Experimental}

$\mathrm{CeO}_{2}$ (s) of $99.9 \%$ purity procured from $\mathrm{M} / \mathrm{s}$. Indian Rare-Earths, India and C(s) with a purity higher than $99.999 \%$, were used for the preparation of the samples. A mixture of $\mathrm{CeO}_{2}(\mathrm{~s})$ and $\mathrm{C}(\mathrm{s})$ in the molar ratio 1:4, was blended and pelletised at a pressure of $25 \mathrm{MPa}$ to give pellets of $6 \mathrm{~mm}$ diameter, $1 \mathrm{~mm}$ thickness and weighing about $100 \mathrm{mg}$. The pellets were heated to the desired temperature and the pressure of $\mathrm{CO}$ effusing out of the pellet, $p_{\text {eff }}$, was recorded as a function of time using the QMS. Details of the experimental procedure employed and the apparatus used have been described in our earlier papers $[2,3]$.

The confirmation of the phases present in the final product was obtained by means of XRD. An independent high-temperature XRD run of the initial sample was carried out using an X-ray diffractometer (X'PERT MPD of M/s. Phillips, Holland), in order to confirm the presence of the required phases at different temperatures in the range 1373-1773 K.

\section{Results}

\subsection{CO pressures}

The effusion pressures of carbon monoxide recorded in the temperature range $1350-1550 \mathrm{~K}$ are given in Table 1. The equilibrium $\mathrm{CO}$ pressures derived at different temperatures were plotted as a function of $1 / T$ (Fig. 1) and fitted to a straight line by the method of least squares. The fit equation is

$\ln p_{\mathrm{CO}}=-(45610 \pm 563) / T+(24.1 \pm 0.4)$,

where $p_{\mathrm{CO}}$ is in bar. 
Table 1

Thermodynamic properties of the $\mathrm{CeO}_{2}(\mathrm{~s})-\mathrm{C}(\mathrm{s})-\mathrm{CeC}_{2}$ (s) system

\begin{tabular}{|c|c|c|c|c|}
\hline Runs & Temperature (in K) & $\begin{array}{l}\text { Equilibrium CO } \\
\text { pressure (in bar) }\end{array}$ & $\begin{array}{l}\Delta_{\mathrm{r}} G^{\circ} \text { of reaction (1) } \\
\left(\text { in } \mathrm{kJ} \mathrm{mol}^{-1} \text { ) }\right.\end{array}$ & $\begin{array}{l}\Delta_{\mathrm{r}} H_{298}^{\circ} \text { of reaction }(1)^{\mathrm{a}} \\
\text { at } 298 \mathrm{~K}\left(\mathrm{in} \mathrm{kJ} \mathrm{mol}^{-1}\right)\end{array}$ \\
\hline \multirow[t]{4}{*}{ Run 1} & 1352 & $7.65 \mathrm{E}-5^{\mathrm{b}}$ & 213.1 & 770.3 \\
\hline & 1372 & $1.11 \mathrm{E}-4$ & 207.7 & 772.9 \\
\hline & 1404 & $2.49 \mathrm{E}-4$ & 193.8 & 771.9 \\
\hline & 1468 & $9.49 \mathrm{E}-4$ & 169.9 & 773.7 \\
\hline \multirow[t]{4}{*}{ Run 2} & 1372 & $1.08 \mathrm{E}-4$ & 208.3 & 773.6 \\
\hline & 1458 & $8.74 \mathrm{E}-4$ & 170.8 & 770.7 \\
\hline & 1496 & $1.81 \mathrm{E}-3$ & 157.2 & 772.0 \\
\hline & 1517 & $3.09 \mathrm{E}-3$ & 145.9 & 769.3 \\
\hline \multirow[t]{4}{*}{ Run 3} & 1375 & $1.24 \mathrm{E}-4$ & 205.8 & 772.4 \\
\hline & 1485 & $1.35 \mathrm{E}-3$ & 163.2 & 773.6 \\
\hline & 1509 & $2.42 \mathrm{E}-3$ & 151.2 & 771.3 \\
\hline & 1541 & $4.27 \mathrm{E}-3$ & 139.8 & 772.5 \\
\hline
\end{tabular}

${ }^{\text {a }}$ Third-law results based on thermal functions of $\mathrm{CaC}_{2}(\mathrm{~s})$.

${ }^{\mathrm{b}}$ Read as $7.65 \times 10^{-5}$.

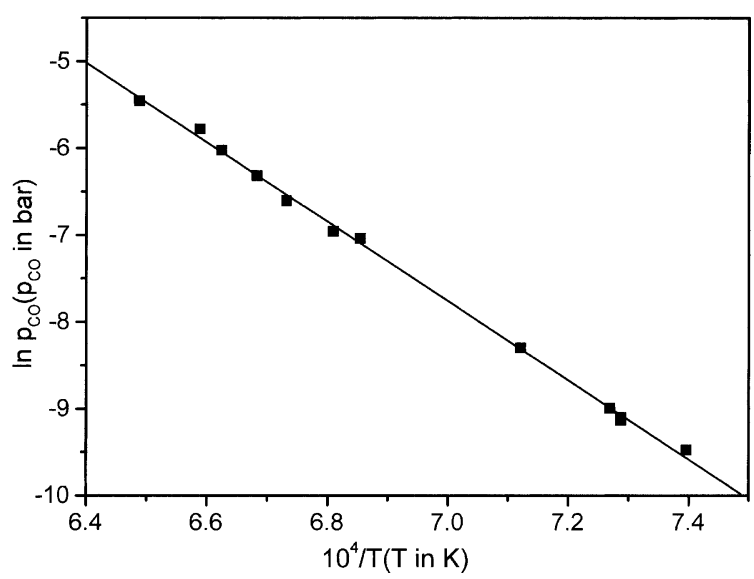

Fig. 1. Plot of equilibrium $\mathrm{CO}(\mathrm{g})$ pressure as derived for reaction (1) against reciprocal temperature.

\subsection{Gibbs energy of formation of $\mathrm{Ce}_{2}(s)$}

The Gibbs energy of reaction (1) at different temperatures was then derived from the respective equilibrium constants. The Gibbs energy of formation of $\mathrm{CeC}_{2}$ (s) at various temperatures was derived from the Gibbs energy of reaction (1) using appropriate Gibbs energy of formation data of $\mathrm{CeO}_{2}$ (s) and $\mathrm{CO}$ from Ref. [19]. A comparison of the Gibbs energy of formation of $\mathrm{CeC}_{2}$ (s) as derived from the present study with the data available in the literature is indicated in Fig. 2.

\subsection{Enthalpy of formation of $\mathrm{CeC}_{2}(s)$}

The second-law enthalpy of reaction (1) at $1446 \mathrm{~K}$ (mid-temperature of measurement) was obtained from

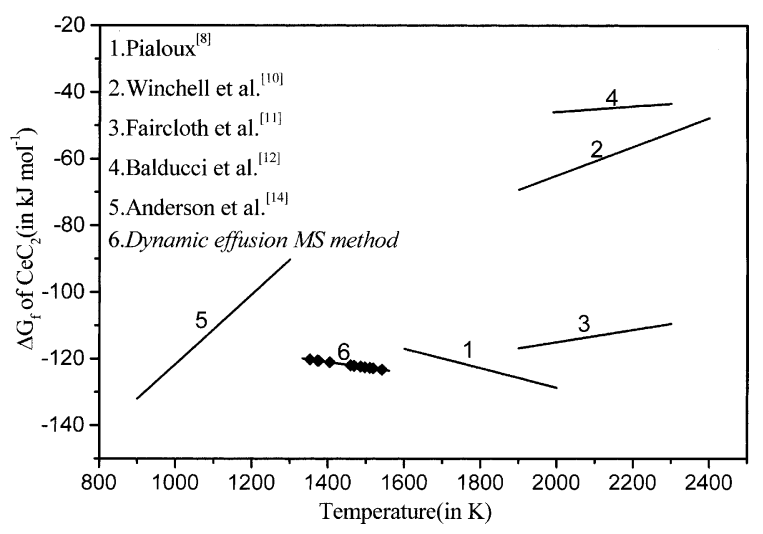

Fig. 2. Comparison of Gibbs energy of formation of $\mathrm{CeC}_{2}(\mathrm{~s})$ obtained in the present study with literature reports.

the slope of the $\ln p_{\mathrm{CO}}$ versus $1 / T$ curve. This was converted to the enthalpy at $298 \mathrm{~K}$ using the enthalpy increments of $\mathrm{CeO}_{2}(\mathrm{~s}), \mathrm{C}(\mathrm{s})$ and $\mathrm{CO}$ from the literature [19]. It is pointed out that most of the researchers have calculated the thermal functions of $\mathrm{CeC}_{2}$ based on those of $\mathrm{CaC}_{2}$. In view of the similarity of the Ce to actinides like $\mathrm{U}, \mathrm{Th}$ it is considered more appropriate to calculate the enthalpy of formation of $\mathrm{CeC}_{2}$ (s) based on the thermal functions of $\mathrm{UC}_{1.94}$ and $\mathrm{ThC}_{1.94}$ by using the second and third-law methods brought out in our earlier paper [2]. Thermal functions for $\mathrm{CeC}_{2}$ (s) were estimated using the thermal functions of iso-structural $\mathrm{CaC}_{2}$, as suggested by Faircloth et al. [11] and using the thermal functions of $\mathrm{UC}_{1.94}$ [19] and $\mathrm{ThC}_{1.94}$ [19]. The $\Delta_{\mathrm{r}} H_{T}^{\circ}(T$ is the mid-temperature of measurement) and $\Delta_{\mathrm{r}} H_{298}^{\circ}$ were found to be $(758.4 \pm 9.0)$ and $(773.8 \pm 9.0) \mathrm{kJ} \mathrm{mol}^{-1}$, respectively, using the enthalpy increments of $\mathrm{CeC}_{2}$ (s) 
derived from those of $\mathrm{CaC}_{2}$ (s) [19]. The second-law enthalpy of reaction (1) at $298 \mathrm{~K}$ calculated using the thermal functions of $\mathrm{CeC}_{2}$ (s) derived from those of $\mathrm{UC}_{1.94}$ and $\mathrm{ThC}_{1.94}$ are $(788.9 \pm 9.0)$ and $(769.2 \pm 9.0)$ $\mathrm{kJ} \mathrm{mol}^{-1}$, respectively. The enthalpy of reaction at $298 \mathrm{~K}$ calculated using the third-law method was found to be (772.5 \pm 1.4$),(750.5 \pm 1.4)$, and $(747.8 \pm 1.4) \mathrm{kJ} \mathrm{mol}^{-1}$ based on the Gibbs energy functions of $\mathrm{CeC}_{2}$ estimated from $\mathrm{CaC}_{2}$ [19], $\mathrm{UC}_{1.94}$ [19] and $\mathrm{ThC}_{1.94}$ [19], respectively. The enthalpy of formation at $298 \mathrm{~K}$ of $\mathrm{CeC}_{2}(\mathrm{~s})$ was then derived from the enthalpy of reaction (1).

Data on the enthalpy of formation of $\mathrm{CeC}_{2}(\mathrm{~s})$ at $298 \mathrm{~K}$ available in the literature are compared with those obtained in the present study, calculated using the thermal functions of $\mathrm{CeC}_{2}(\mathrm{~s})$ derived from the thermal functions of $\mathrm{CaC}_{2}, \mathrm{UC}_{1.94}$ and $\mathrm{ThC}_{1.94}$ in Table 2.

\subsection{Confirmation of the phases}

The XRD pattern of the sample at the end of the measurement indicated the presence of the three-phase mixture of $\mathrm{CeO}_{2}(\mathrm{~s}), \mathrm{CeC}_{2}(\mathrm{~s})$ and $\mathrm{C}(\mathrm{s})$. The XRD patterns of the oxide-graphite mixture, heated to temperatures 1373-1773 K (given in Fig. 3) also indicate the presence of the oxide-carbide-graphite equilibrium from $1373 \mathrm{~K}$ onwards. The lattice parameters of $\mathrm{CeC}_{2}(\mathrm{~s})$ were deduced to be $a=386 \mathrm{pm}$ and $c=649 \mathrm{pm}$ (room temperature values). The measured average lattice parameter of $\mathrm{CeO}_{2}$ was found to $540 \mathrm{pm}$.

\subsection{Errors in the measurement}

The uncertainty in the temperature is $\pm 3 \mathrm{~K}$, and the error in the pressure measurements for different samples heated to the same temperature is estimated to be less than $5 \%$. The error in the $\Delta_{\mathrm{f}} G^{\circ}$ measurements, assuming all these factors, is about $6 \mathrm{~kJ} \mathrm{~mol}^{-1}$. The enthalpy and Gibbs energy functions of $\mathrm{CeO}_{2}(\mathrm{~s}), \mathrm{C}(\mathrm{s})$ and $\mathrm{CO}$ have been taken from a well-established database [19], while the functions of $\mathrm{CeC}_{2}(\mathrm{~s})$ are estimated from data of $\mathrm{UC}_{1.94}$ and $\mathrm{ThC}_{1.94}$ as experimental data are not available. The error in the enthalpy measurements using the second-law treatment is about $9.0 \mathrm{~kJ} \mathrm{~mol}^{-1}$ and by thirdlaw analysis is about $1.4 \mathrm{~kJ} \mathrm{~mol}^{-1}$. Considering the error in $\Delta_{\mathrm{f}} G^{\circ}$, the overall error in the reported data of the enthalpy of formation of carbide is about $11.0 \mathrm{~kJ} \mathrm{~mol}^{-1}$.

\section{Discussion and conclusion}

\subsection{Absence of oxicarbide phase formation}

The lattice parameter of $\mathrm{CeC}_{2}(\mathrm{~s})$ as deduced from the XRD data in the present study corresponds to the lowtemperature tetragonal $\alpha$-phase. Pialoux [8] has indicated the presence of two large univariant fields $\left[\mathrm{Ce}_{2} \mathrm{O}_{3}\right.$, $\left.\beta-\mathrm{Ce}_{2} \mathrm{O}_{2} \mathrm{C}_{2}, \mathrm{C}, \mathrm{CO}\right]$ and $\left[\beta-\mathrm{Ce}_{2} \mathrm{O}_{2} \mathrm{C}_{2}, \mathrm{C}, \mathrm{CO}, \beta-\mathrm{CeC}_{2}\right]$ in the reported phase diagram of $\mathrm{Ce}-\mathrm{C}-\mathrm{O}$ and has determined the equilibrium $\mathrm{CO}$ pressure for both these phase fields. The carbothermic reduction was perceived to be

Table 2

Enthalpy of formation of $\mathrm{CeC}_{2}(\mathrm{~s})$

\begin{tabular}{|c|c|c|c|c|}
\hline \multirow[t]{2}{*}{ Method/technique } & \multicolumn{3}{|c|}{$\Delta H_{\mathrm{f} 298 \mathrm{~K}}^{\circ}\left(\mathrm{kJ} \mathrm{mol}^{-1}\right)$} & \multirow[t]{2}{*}{ Reference } \\
\hline & Second law & Third law & Selected & \\
\hline \multirow[t]{2}{*}{ Controlled CO pressure } & & & $-93.8(\alpha)$ & \\
\hline & $-91.7^{\mathrm{a}}$ & $-93.8^{\mathrm{a}}$ & $-73.8(\beta)$ & Pialoux [8] \\
\hline Knudsen cell MS & -81.6 & - & -81.6 & $\begin{array}{l}\text { Winchell and Baldwin } \\
{[10]}\end{array}$ \\
\hline Knudsen effusion & -104.7 & -207.9 & -104.7 & Faircloth et al. [11] \\
\hline Knudsen cell MS & $-62.7 \pm 21$ & $-71.5 \pm 21$ & $-62.7 \pm 21$ & Balducci et al. [12] \\
\hline Bomb calorimetry & - & - & $-97.2 \pm 5.4$ & Baker et al. [13] \\
\hline EMF & -219 & $-88.5 \pm 10.5$ & $-88.5 \pm 10.5$ & $\begin{array}{l}\text { Anderson and Bagshaw } \\
{[14]}\end{array}$ \\
\hline Synthesis calorimetry & - & - & $-76.2 \pm 4.2$ & $\begin{array}{l}\text { Meschel and Kleppa } \\
{[15]}\end{array}$ \\
\hline Estimation & - & - & -186 & Niessen et al. [18] \\
\hline \multirow[t]{4}{*}{$\begin{array}{l}\text { Dynamic effusion MS } \\
\text { method }\end{array}$} & & & & $\begin{array}{l}\text { Using thermal functions } \\
\text { of }\end{array}$ \\
\hline & $-95.5 \pm 9.0$ & $-96.8 \pm 1.4$ & & $\mathrm{CaC}_{2}$ \\
\hline & $-80.1 \pm 9.0$ & $-118.8 \pm 1.4$ & & $\mathrm{UC}_{1.94}$ \\
\hline & $-100.1 \pm 9.0$ & $-121.4 \pm 1.4$ & $-120.1 \pm 11.0^{\mathrm{b}}$ & $\mathrm{ThC}_{1.94}$ \\
\hline
\end{tabular}

\footnotetext{
${ }^{\mathrm{a}}$ Thermal functions of $\mathrm{CeC}_{2}(\mathrm{~s})$ have been derived from those of $\mathrm{LaC}_{2}(\mathrm{~s})$.

${ }^{\mathrm{b}} \mathrm{Recommended}$ value with the overall estimated error in the measurement.
} 


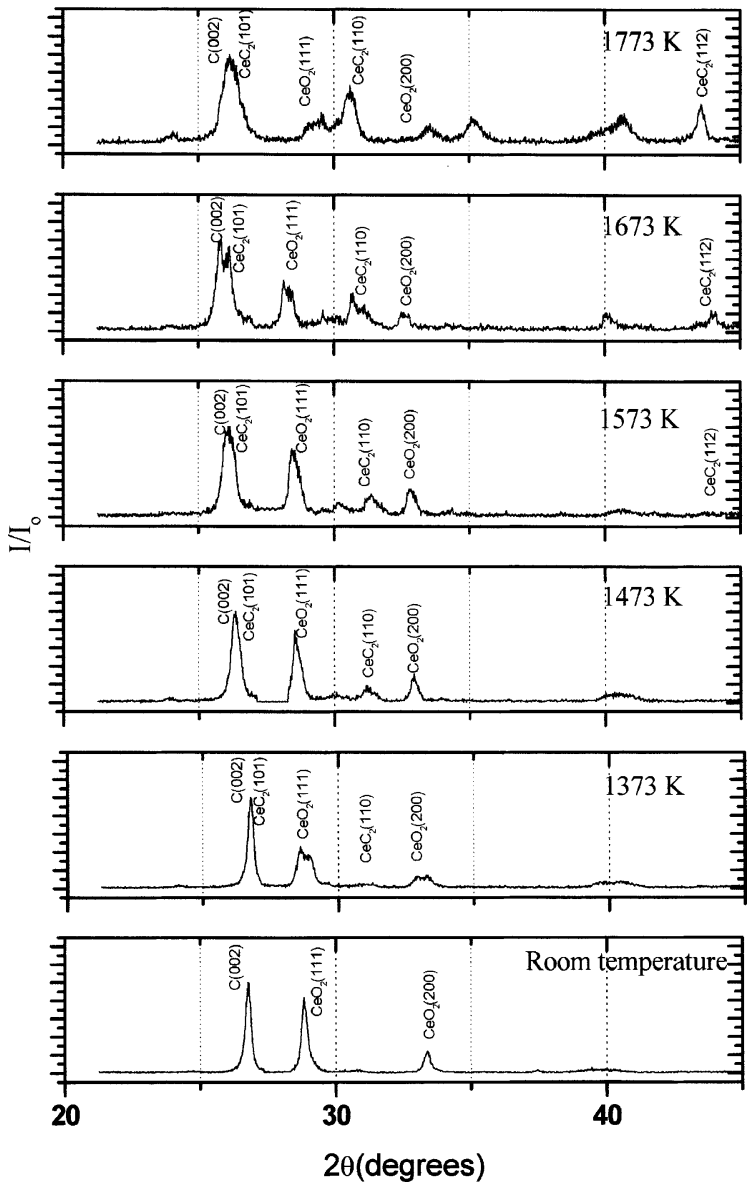

Fig. 3. High temperature XRD patterns of $\mathrm{Ce}-\mathrm{C}-\mathrm{O}$ system.

comprising of two steps, wherein the first step involves the formation of the oxicarbide while in the second step the oxicarbide decomposes to form the $\beta-\mathrm{CeC}_{2}$ with the evolution of $\mathrm{CO}$ gas.

The formation of oxicarbide during the carbothermic reduction in the present study has been ruled out on the following basis. First, the oxicarbide is reported [8] to have a hexagonal symmetry and its characteristic diffraction pattern was not observed in the present study. The oxicarbide is reported to be a limiting composition for an isomorphous replacement of $\mathrm{O}^{2-}$ with $\mathrm{C}_{2}^{2-}$ in hexagonal $\mathrm{Ce}_{2} \mathrm{O}_{3}$ [7]. The hexagonal oxicarbide phase has been reported to be in equilibrium with hexagonal $\mathrm{Ce}_{2} \mathrm{O}_{3}$ and the $\beta-\mathrm{CeC}_{2}$ phases [8]. In the present case, the final product did not indicate either the presence of $\mathrm{Ce}_{2} \mathrm{O}_{3}$ or $\beta-\mathrm{CeC}_{2}$. Also the $\beta-\mathrm{Ce}_{2} \mathrm{O}_{2} \mathrm{C}_{2}$ is a high-temperature phase which is stable only above $1600 \mathrm{~K}$, while all our measurements have been carried out below 1550 $\mathrm{K}$. An independent thermo-gravimetric investigation of the carbothermic reduction of $\mathrm{CeO}_{2}$ at $1400 \mathrm{~K}$ revealed the reaction to be a single-step process [20] which rules

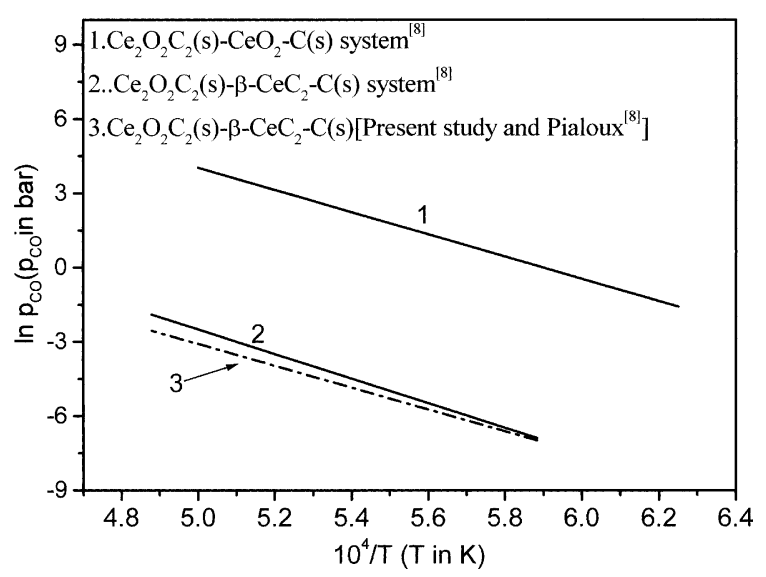

Fig. 4. Plot of equilibrium $\mathrm{CO}(\mathrm{g})$ pressure for the formation and decomposition of $\beta-\mathrm{Ce}_{2} \mathrm{O}_{2} \mathrm{C}_{2}(\mathrm{~s})$.

out the possibility of any intermediate oxicarbide phase formation.

The equilibrium $\mathrm{CO}$ pressures obtained in this study are much lower than that reported by Pialoux [8] for the formation of $\beta-\mathrm{Ce}_{2} \mathrm{O}_{2} \mathrm{C}_{2}$ (according to Eq. (3))

$\mathrm{Ce}_{2} \mathrm{O}_{3}+3 \mathrm{C}=\beta-\mathrm{Ce}_{2} \mathrm{O}_{2} \mathrm{C}_{2}+\mathrm{CO}$

indicating the absence of the co-existence of the oxidegraphite-oxicarbide phases in the present study. The limiting pressures for the decomposition of $\beta-\mathrm{Ce}_{2} \mathrm{O}_{2} \mathrm{C}_{2}$ (Eq. (4)) are plotted in Fig. 4

$\beta-\mathrm{Ce}_{2} \mathrm{O}_{2} \mathrm{C}_{2}+4 \mathrm{C}=2 \beta-\mathrm{CeC}_{2}+2 \mathrm{CO}$

The limiting pressures were calculated by using $\Delta_{\mathrm{f}} G^{\circ}$ of $\beta-\mathrm{Ce}_{2} \mathrm{O}_{2} \mathrm{C}_{2}$ from the results of Pialoux [8] and the $\Delta_{\mathrm{f}} G^{\circ}$ of $\beta-\mathrm{CeC}_{2}$ was derived from the data obtained in the present study for $\Delta_{\mathrm{f}} G^{\circ}$ of $\alpha-\mathrm{CeC}_{2}$. A good agreement between the results from the present study with the equilibrium $\mathrm{CO}$ pressures (for Eq. (4)) reported by Pialoux [8] (Fig. 4) has been observed. Since a similar carbothermic reduction method has been adopted by Pialoux [8], the agreement of equilibrium $\mathrm{CO}$ pressures indicates the reliability of our measurements. Thus the presence of oxicarbide phases in the condensed phase is ruled out. Also the presence of excess carbon ensures the absence of a sesquicarbide phase. The XRD pattern shows no characteristic pattern for sesquicarbide.

\subsection{Gibbs energy of formation}

Fig. 2 indicates a comparison of the Gibbs energy of formation of $\mathrm{CeC}_{2}(\mathrm{~s})$ obtained in the present study (calculated using the thermal functions of $\mathrm{CeC}_{2}$ derived from those of $\mathrm{CaC}_{2}$ ) with the literature reports. There is a scatter in the reported data and the results obtained in the present study agree reasonably within the limits of experimental error with the report of Pialoux [8] who 
has adopted a carbothermic reduction method. The reported results of Faircloth et al. [11] also agree reasonably well with the present results, while the results of Anderson and Bagshaw [14] show a steep temperature variation of the Gibbs energy of formation with temperature. The Gibbs energy of formation reported by Winchell and Baldwin [10] and Balducci et al. [12] are more positive than that reported by other investigators. The entropy change at this temperature range is about $16 \mathrm{~J} \mathrm{~K}^{-1} \mathrm{~mol}^{-1}$ in the present study. The standard entropy of formation of $\mathrm{CeC}_{2}(\mathrm{~s})$ at $298 \mathrm{~K}$ is about 103.6 $\mathrm{J} \mathrm{K}^{-1} \mathrm{~mol}^{-1}$.

\subsection{Enthalpy of formation}

Since thermal functions of $\mathrm{CaC}_{2}$ were used in deducing the thermal functions of $\mathrm{CeC}_{2}$ in most of the reports listed in Table 2 for the purpose of comparison, the second and third-law enthalpies for reaction 1 were calculated based on the thermal functions of $\mathrm{CeC}_{2}$ derived from those of $\mathrm{CaC}_{2}$. The calculated enthalpies are in agreement, within about $\pm 2 \mathrm{~kJ} \mathrm{~mol}^{-1}$. As it is evident from Table 1, there is no significant temperature dependent variation of the third-law enthalpy of reaction indicating the reliability of the thermodynamic data obtained.

Winchell and Baldwin [10] apportioned the total pressure, measured over $\mathrm{CeC}_{2}(\mathrm{~s})$, between $p_{\mathrm{Ce}}$ and $p_{\mathrm{CeC}_{2}}$ by taking the ratio of $\mathrm{Ce} / \mathrm{CeC}_{2}$ as reported by Balducci et al. [21]. Winchell and Baldwin [10] have not observed a significant $\mathrm{Ce}^{+}$signal (arising from the presence of $\mathrm{Ce}$ vapour over the $\mathrm{CeC}_{2}$ phase) in their mass spectrometric study. In a more recent paper, Balducci et al. [12] have contradicted this observation and have reported that the $\mathrm{Ce}^{+}$signal was found more prominently than that of $\mathrm{CeC}_{2}^{+}$. Hence, the ratio $\left(\mathrm{CeC}_{2} / \mathrm{Ce}\right)$ used by Balducci et al. [12] for their calculations are different.

Faircloth et al. [11] have obtained the $\mathrm{CeC}_{2}(\mathrm{~s})-\mathrm{C}(\mathrm{s})$ phases by heating a mixture of cerium and graphite in a Knudsen cell above $2000 \mathrm{~K}$, wherein the possibility of the formation of non-stoichiometric $\mathrm{CeC}_{2+x}$ (where $x=0.34$ ) cannot be ruled out. The total pressure was apportioned based on the ratio reported by Balducci et al. [21]. The second and third-law enthalpies of the reaction also varied widely. They have chosen the enthalpy of formation obtained by the second-law method as the recommended value. The calculation of the enthalpy and Gibbs energy is sensitive to the $p_{\mathrm{CeC}_{2}} / p_{\mathrm{Ce}}$ ratio, which varies from 0.77 to 4 in various measurements. Since the data from the measurements involve the apportioning of the total pressure, which in turn depends on the ratio used for calculation, a lot of error is bound to be associated with these measurements. There is a large disagreement between the second-law ( -219 $\mathrm{kJ} \mathrm{mol}^{-1}$ ) and third-law $\left(-88.8 \mathrm{~kJ} \mathrm{~mol}^{-1}\right.$ ) results of Anderson and Bagshaw [14] and the third-law data are recommended. As indicated by the authors themselves, caution should be exercised in using galvanic cells to determine reliable thermochemical information on refractory materials. The results of Meschel and Kleppa [15] are also more positive by about $20 \mathrm{~kJ} \mathrm{~mol}^{-1}$ than the reported results in the present study. The estimated results of Niessen et al. [18] are highly negative. Pialoux [8] has derived the enthalpy increments and the Gibbs energy functions of $\mathrm{CeC}_{2}$ (s) from those of $\mathrm{LaC}_{2}$ (s). From Table 2, it is obvious that our results (based on calculations with $\mathrm{CaC}_{2}$ thermal function) agree well with the results of Pialoux [8] and Baker et al. [13]. As pointed out earlier, all the previous authors have used the thermal functions of $\mathrm{CeC}_{2}$ derived from those of $\mathrm{CaC}_{2}$ to evaluate the third-law enthalpy of formation of $\mathrm{CeC}_{2}(\mathrm{~s})$. It would be more appropriate to use the thermal functions of $\mathrm{ThC}_{1.94}$ or $\mathrm{UC}_{1.94}$ for this purpose, due to similarity of cerium with actinides. The average of the results obtained by using the Gibbs energy functions of $\mathrm{UC}_{1.94}$ and $\mathrm{ThC}_{1.94},(120.1 \pm 11.0) \mathrm{kJ} \mathrm{mol}^{-1}$, is chosen to be the recommended value for $\Delta_{\mathrm{f}} H_{298}^{\circ}$ of $\mathrm{CeC}_{2}(\mathrm{~s})$. However, it is observed that the second and third-law enthalpies derived using the thermal functions of $\mathrm{CeC}_{2}$ which were deduced from those of $\mathrm{UC}_{1.94}$ and $\mathrm{ThC}_{1.94}$ are not in agreement. The same was also observed in our previous studies with $\mathrm{La}-\mathrm{C}$ and $\mathrm{Nd}-\mathrm{C}$ systems $[2,3]$. The difference could arise due to the variation in the enthalpy increment and Gibbs energy function for calculation. The reliability of these functions is yet to be established.

\section{Summary}

The equilibrium carbon monoxide pressures over the three-phase mixture of $\mathrm{CeO}_{2}(\mathrm{~s}), \mathrm{C}(\mathrm{s})$ and $\mathrm{CeC}_{2}(\mathrm{~s})$ were measured in order to determine the thermodynamic data on $\mathrm{CeC}_{2}$ (s). The enthalpy of formation and the Gibbs energy of formation of $\mathrm{CeC}_{2}$ (s) at $298 \mathrm{~K}$ calculated from the present study are: $(120.1 \pm 11.0)$ and $(103.0 \pm 6.0)$ $\mathrm{kJ} \mathrm{mol}^{-1}$, respectively.

\section{References}

[1] Hj. Matzke, Science of Advanced LMFBR Fuels, NorthHolland, Amsterdam, 1986.

[2] R. Vidhya, M.P. Antony, P.R. Vasudeva Rao, B. Viswanathan, J. Nucl. Mater. 295 (2001) 221.

[3] R. Vidhya, M.P. Antony, P.R. Vasudeva Rao, B. Viswanathan, J. Nucl. Mater. 295 (2001) 228.

[4] R. Vidhya, M.P. Antony, C.K. Mathews, J. Phys. Chem. 99 (1995) 16468.

[5] G.-y. Adachi, N. Imanaka, Z. Fuzhong, in: Handbook on the Physics and Chemistry of Rare-earths, vol. 15, NorthHolland, Amsterdam, 1991, p. 61.

[6] N.J. Clark, I.J. McColm, J. Inorg. Nucl. Chem. 34 (1972) 117. 
[7] J.S. Anderson, A.N. Bagshaw, in: Les Elements des Terres Rares, Centre National de la Recherche Scientifique, Paris, vol. 1, 1970, p. 397.

[8] A. Pialoux, J. Less Commun. Metals 143 (1988) 219.

[9] E. Kingcade, D.L. Cocke, K.A. Gingerich, Inorg. Chem. 23 (1984) 1334.

[10] P. Winchell, N.L. Baldwin, J. Phys. Chem. 71 (1967) 4476.

[11] R.L. Faircloth, R.H. Flowers, F.C.W. Pummery, J. Inorg. Nucl. Chem. 30 (1968) 499.

[12] G. Balducci, A. Capalbi, G. De Maria, M. Guido, J. Chem. Phys. 50 (1969) 1969.

[13] F.B. Baker, E.J. Huber Jr., C.E. Holley Jr., N.H. Krikorian, J. Chem. Thermodyn. 3 (1970) 77.

[14] J.S. Anderson, A.N. Bagshaw, Rev. Chim. Miner. 9 (1972) 115.
[15] S.V. Meschel, O.J. Kleppa, J. Alloys Compds. 220 (1995) 88.

[16] K.A. Gschneidner Jr., N. Kippenhan, US Rare Earth Information Center, Iowa Report IS-RIC-5, 1971.

[17] K.A. Gschneidner, F.W. Calderwood, Bull. Alloy Phase Diag. 7 (1986) 421.

[18] A.K. Niessen, F.R. deBoer, R. Boom, P.F. deChatel, W.C.M. Mattens, A.R. Miedema, Calphad 7 (1983) 51.

[19] O. Kubaschewski, O. Knacke, K. Hesselmann, Thermochemical Properties of Inorganic Substances, 2nd Ed., Springer-Verlag, Berlin, 1991.

[20] K. Joseph, Private Communication, 2000.

[21] G. Balducci, A. Capalbi, G. De Maria, M. Guido, J. Chem. Phys. 43 (1965) 2136. 